日臨外会誌 $66(7), 1656-1659,2005$

症例

炎症所見を認めなかった魚骨による虫垂穿孔の 1 例

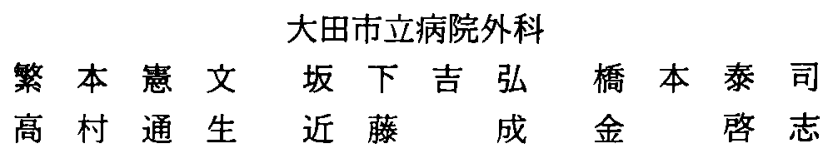

炎症所見を認めなかった魚骨による虫垂穿孔の 1 例を経験した。症例は55歳, 男性. 右下腹部痛を主訴に来院した。血液検㚗と画像検査にて炎症所見を認めなかったが，理 学的所見から急性虫垂炎などの炎症性疾患を否定しえなかった。手術を施行し魚骨によ る虫垂穿孔と診断した. 誤篧された魚骨が虫垂を穿孔することは稀である. 1989年以降， 本邦に於いて報告された魚骨による虫垂穿孔例は自験例を含め18例であった．多くは虫 垂炎や回盲部膿瘍などの炎症性疾患の術前診断にて開腹手術が施行されており, 術前に 診断に至ったものは 3 例であった，また，血液検查，画像検査にて異常を指摘できなか った例が 2 例みられ，理学的所見を軽視できないことが示唆された．文献的考察を加え て報告する。

索引用語：虫垂穿孔，異物，魚骨

緒言

誤噯された魚骨は通常消化されるか 1 週間以内に自 然排泄されるといわれている，稀に消化管を穿孔し治 療対象となることがあるが, 肛門部での穿通症例が多 く, 虫垂穿孔例は少数である”. 今回われわれは血液検 査と画像検査にて炎症所見を認めず，理学的所見から 急性虫垂炎を疑い，術中魚骨による虫垂穿孔と診断し た症例を経験したので文献的考察を加えて報告する.

$$
\text { 症例 }
$$

患者：55歳, 男性.

家族歴，既往歴：特記すべきことなし。

現病歴: 平成16年 7 月 1 日, 起床時に右下腹部痛を 自覚した. 以後，1日1〜2回痛みを自覚していた。 食事，便通に異常を認めなかったが，歩行時に右下腹 部にひびくようになり，7月 7 日，近医受診した。右 下腹部に圧痛と同部位に反跳痛を認めた。虫垂炎疑い にて，7月8日，当科紹介された。

入院時現症：身長 $172 \mathrm{~cm}$, 体重 $62.6 \mathrm{~kg}$. 体温 $36.6^{\circ} \mathrm{C}$. 右下腹部に軽度の自発痛を認め, 歩行時にやや増悪し た。圧迫すると刺されたような激痛を認めた，圧痛部

2005年 1 月 7 日受付 2005 年 5 月 9 日採用 〈所属施設住所〉

干694-0063 大田市大田町吉永1428-3
位は限局しており，同部位に反跳痛を認めた，筋性防 御は認めなかった。

入院時一般検查所見 : WBC $3,900 \mathrm{~mm}^{3}$, CRP 0.0 $\mathrm{mg} / \mathrm{dl}$ と炎症所見を認めなかった. $\gamma$-GTP 71IU/L と 軽度高值を示した以外に, 異常所見は認めなかった(表 1 ).

腹部単純 X 線：イレウスの所見なく，その他にも明 らかな異常所見を認めなかった（図 1 ).

腹部単純造影 CT：腹腔内に炎症や腫瘍を示唆する 所見は認めなかった（図 2 )。

表 1 入院時検查所見

\begin{tabular}{|c|c|c|c|c|c|}
\hline WBC & 3,900 & $/ \mathrm{mm}^{3}$ & LAP & 147 & $\mathrm{IU} / 1$ \\
\hline RBC & $390 \times 10^{4}$ & $/ \mathrm{mm}^{3}$ & ChE & 298 & $\mathrm{IU} / 1$ \\
\hline $\mathrm{Hb}$ & 14.3 & $\mathrm{~g} / \mathrm{dl}$ & CPK & 183 & IU/1 \\
\hline $\mathrm{Ht}$ & 41.3 & $\%$ & CRP & 0.0 & $\mathrm{mg} / \mathrm{dl}$ \\
\hline Plt & $16.7 \times 10^{4}$ & $/ \mathrm{mm}^{3}$ & $\mathrm{Na}$ & 146 & $\mathrm{mEq} / \mathrm{l}$ \\
\hline$T P$ & 7.2 & $\mathrm{~g} / \mathrm{dl}$ & $\mathrm{K}$ & 4.6 & $\mathrm{mEq} / \mathrm{l}$ \\
\hline Alb & 4.3 & $\mathrm{~g} / \mathrm{dl}$ & $\mathrm{Cl}$ & 109 & $\mathrm{mEq} / \mathrm{l}$ \\
\hline Bil & 0.5 & $\mathrm{mg} / \mathrm{dl}$ & BUN & 10.5 & $\mathrm{mg} / \mathrm{dl}$ \\
\hline AST & 32 & $\mathrm{IU} / 1$ & $\mathrm{Cr}$ & 0.71 & $\mathrm{mg} / \mathrm{dl}$ \\
\hline ALT & 23 & $\mathrm{IU} / \mathrm{l}$ & BS & 95 & $\mathrm{mg} / \mathrm{dl}$ \\
\hline LDH & 222 & $\mathrm{IU} / 1$ & $\mathrm{PT}$ (INR) & 0.97 & \\
\hline$\gamma-\mathrm{GTP}$ & 71 & $\mathrm{IU} / 1$ & APTT & 27.9 & $\mathrm{sec}$ \\
\hline ALP & 229 & $\mathrm{IU} / 1$ & 杘潜血 & 陰性 & \\
\hline
\end{tabular}




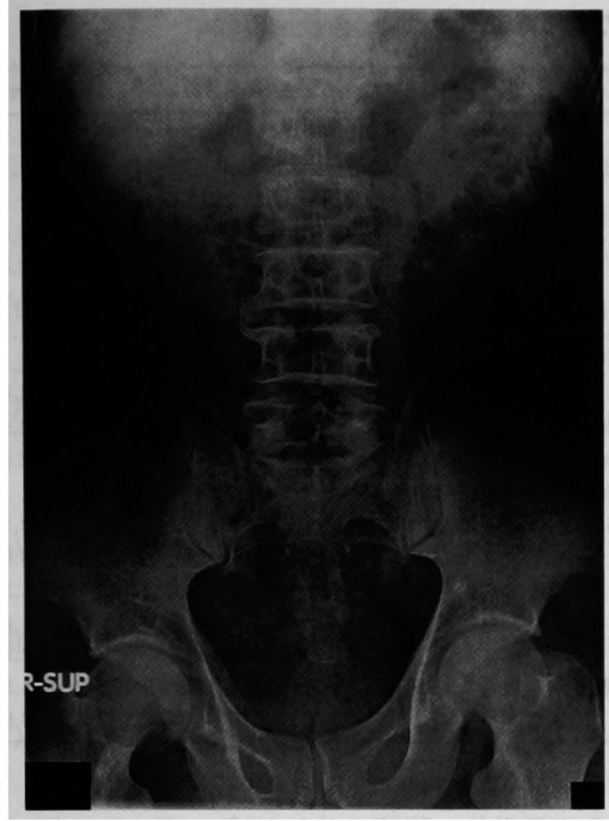

図 1 腹部単純 $\mathrm{X}$ 線：明らかな異常所見を認め ない.

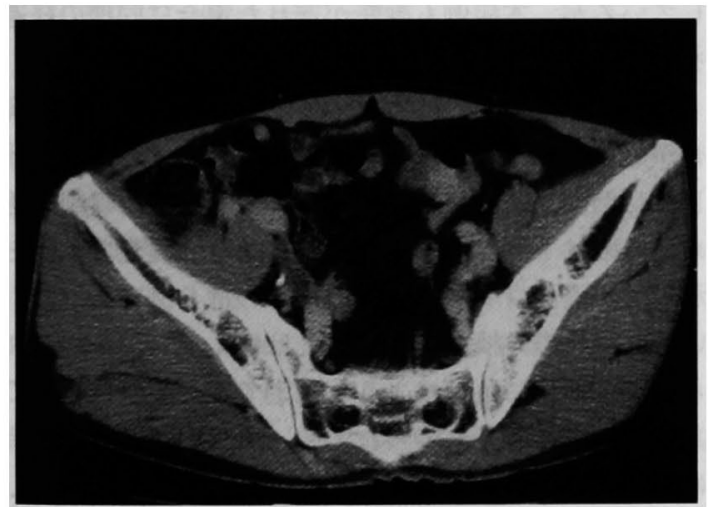

図 2 腹部造影 CT：腹腔内に炎症や腫癌を示唆する所 見を認めない，尿管内の造影剤が高吸収域となってい るほかに魚骨を疑わせる高吸収域を認めない。

理学的所見から虫垂炎を鑑別診断に挙げたが，明ら かな炎症所見を認めなかった。しかし，右下腹部に著 明な圧痛を認めたことから急性虫垂炎などの炎症性疾 患を否定しえず，開腹手術を施行した。

手術所見：右傍正中切開法にて開腹した。腹腔内に は嶈液性腹水を少量認めた。上行結腸を同定し，結腸 ヒモを口側にたどり虫垂を同定した。虫垂の先端付近 の漿膜面に約 $3 \mathrm{~mm}$ の棘状物が突出していた．右下腹

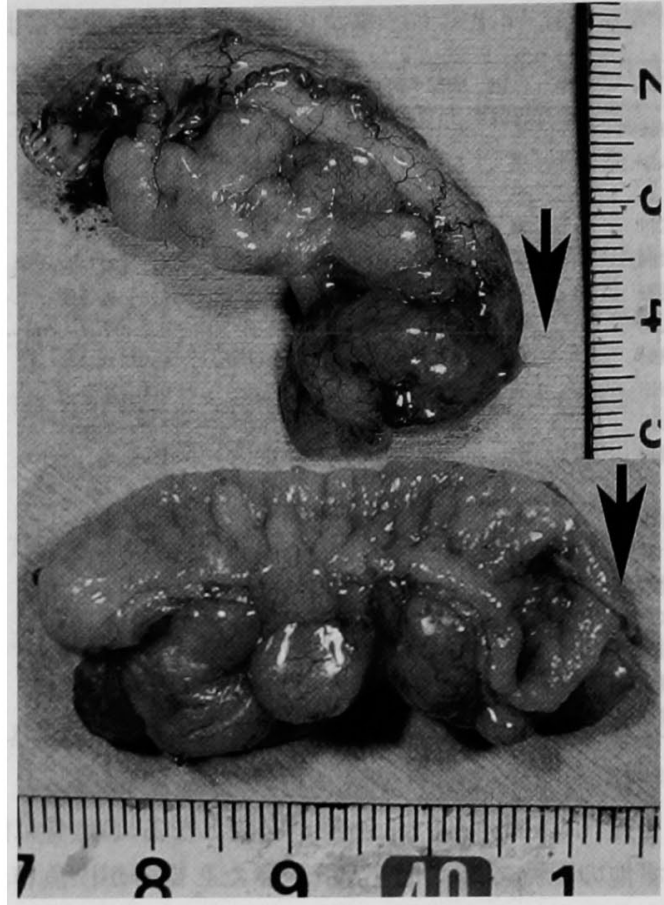

図 3 虫垂切除標本：a）禁膜面に約 $3 \mathrm{~mm}$ の䊂状物 が突出している．b)内腔に $20 \mathrm{~mm}$ 長の魚骨を認め る.鈍端が虫筀先端に向かい. 鋭端が虫垂壁を穿孔 している、粘膜面，整膜面とも肉眼的に炎症所見を 認めない。 $\frac{\mathrm{a}}{\mathrm{b}}$

部の刺されたような激痛の原因として妥当であり，他 の検査所見と矛盾しないことより，これを責任病巣と 判断し虫垂切除術を施行した。周囲腸管には損傷を諮 めなかった。

切除標本：虫垂は $5 \times 1 \mathrm{~cm}$. 内腔に $20 \mathrm{~mm}$ 長の魚骨 を認め，鈍端が虫垂先端に向かい，鋭端が虫垂壁を穿 孔していた。粘膜面, 禁膜面とも肉眼的に炎症所見を 認めなかった（図 $3 \mathbf{a} ， \mathbf{b}$ ).

病理組織学的所見：比較的好中球浸潤が多い部位が みられたが，炎症所見は軽度であった。

術後経過は良好で, 術後 7 日目に退院となった。術 後の詳細な問診によると，元来，魚の摄食量が多く， 早食いであった．時折魚の骨を飲み込んでしまうこと があり，発症数日前にも魚（カサゴ）を悢食したとの ことであった。

\section{考 察}

誤嚓された魚骨は一般に消化されるか 1 週間以内に 自然排泄され，臨床症状を呈さないが，時として消化 
表 2 魚骨による虫垂穿孔の本邦報告例

\begin{tabular}{|c|c|c|c|c|c|c|c|c|c|c|}
\hline 定例 & 年魿 & 性㓢 & 膻部手術歴 & WBC & CRP & 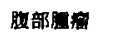 & CT 所見 & エコー所見 & 術前昣断 & 急霄最 \\
\hline 自例 & 55 & 男 & なし & 4.000 & $<0.3$ & なし & 蝟营なし & 暴常なし & 急性虫垂炎 & $2.0 \mathrm{~cm}$ \\
\hline 久下 & 43 & 男 & なし & 13,300 & 7.6 & なし & $1.5 \mathrm{~cm}$ 大の線扰 $\mathrm{HAD}$ & 記载なし & 筷石を伴う急性虫垂炎 & $2.5 \mathrm{~cm}$ \\
\hline 北片 & 69 & 为 & なし & 10,800 & 12.9 & $7 \mathrm{~cm}$ & 線状影 & 毁截なし & 魚胡による虫垂穿孔 & $2.5 \mathrm{~cm}$ \\
\hline 二树 & 30 & 男 & なし & 6,900 & 異常なし & なし & 䟕武なし & 吐载なし & 急性虫垂炎 & $2.6 \mathrm{~cm}$ \\
\hline 犬京 & 59 & 男 & なし & 7.100 & 14.1 & なし & 記䑾なし & 内部に高ェコー & 急性虫垂炎 & $2.0 \mathrm{~cm}$ \\
\hline 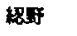 & 48 & 女 & r & 16.400 & 10.8 & 弹性硕 & 内部に石灰化 & 綜状高エコー & 急性虫垂炎 & $2.0 \mathrm{~cm}$ \\
\hline 娃川 & 70 & 女 & 卵管結果洞 & 6.600 & 6.7 & $7 \times 4 \mathrm{~cm}$ & 内部不均一 & 内部モザイク状 & 虫垂艒 & $1.2 \mathrm{~cm}$ \\
\hline 野 & 59 & 男 & なし & 9,300 & 0.7 & tL & 維上 HAD & 蚁载なし & 急性蛏筑 & $1.1 \mathrm{~cm}$ \\
\hline 柴田 & 55 & 男 & なし & 13,110 & 0.1 & 手样大 & 倩線状高吸収域 & 郡柀なし & 絞拒性イレウス & $5.0 \mathrm{~cm}$ \\
\hline 捪川 & 51 & 男 & 幽門側周切除術 & 21,300 & 21.8 & $10 \mathrm{~cm}$ & 異物とみられる高吸収域 & 緗状高エコー & 異物による腹腆炎 & $2.5 \mathrm{~cm}$ \\
\hline 藤村 & 64 & 男 & なし & 14.100 & 21.2 & なし & $\begin{array}{l}5 \times 3 \mathrm{~cm} \text { 低吸収城，内 } \\
\text { 部に } 2 \mathrm{~cm} \text { 程の高吸收城 }\end{array}$ & $\begin{array}{l}\text { 内部に非劳に賟度の高い } \\
2.5 \mathrm{~cm} \text { 長の線状高エコー }\end{array}$ & $\begin{array}{l}\text { 魚骨の消化管穿孔による } \\
\text { 炎应性肉芽目 }\end{array}$ & $3.5 \mathrm{~cm}$ \\
\hline 志田 & 54 & 男 & なし & 10.920 & $1 . x$ & 䄪 $5 \mathrm{~cm}$ & 直佳 $5 \mathrm{~cm}$ の虺的 & 直徍 $5 \mathrm{~cm}$ の道的 & 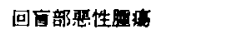 & $2.2 \mathrm{~cm}$ \\
\hline 小陆 & 61 & 男 & なL & 14.900 & 36.1 & なし & 钎蛲なし & $4 \times 3 \mathrm{~cm}$ 大の低エコー域 & 虫垂炎穿れ，腹腔内脿的 & $3.0 \mathrm{~cm}$ \\
\hline 違近 & 78 & 女 & なし & 5.900 & & $4 \mathrm{~cm}$ 大 & 記䑾なし & 約 $5 \mathrm{~mm}$ の高エコー領域 & 急性虫垂炎 & $1.3 \mathrm{~cm}$ \\
\hline 火爪 & 55 & 男 & なし & 12.400 & 2.6 & なし & 記船なし & 記鐡なし & 急性虫垂资 & $1.8 \mathrm{~cm}$ \\
\hline 村消 & 48 & 男 & 胃切除術 & 12.900 & 4.6 & 小児手数大 & 被包化䐦的 & 記軄なし & 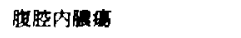 & $2.0 \mathrm{~cm}$ \\
\hline 频田 & 56 & 男 & 幽門側四切给術 & 5,500 & 記鹤なし & 霓卵大 & 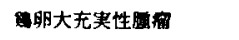 & 核のよ5な高的度颃域 & 原発性虫垂密 & $1.8 \mathrm{~cm}$ \\
\hline 䡒挥 & 53 & 男 & なし & 15.200 & $6+$ & なし & 記諓なし & 記载なし & 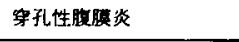 & $3.0 \mathrm{~cm}$ \\
\hline
\end{tabular}

管を穿孔ないし穿通し, 治療が必要となる”。魚骨に限 らず他の異物でも消化管穿孔をきたし得るが，魚を食 する生活習慣から本邦では魚骨が原因となることが多 い.

石橋”は喂下性異物症例の270例の集計で, 穿孔例78 例中34例 $(43.6 \%)$ が魚骨によるものであったと述へ ている.松井ら 21 は魚骨による消化管穿通を集計し, 穿 通部位のはっきりした92例中, 肚門が最も多く27例で,

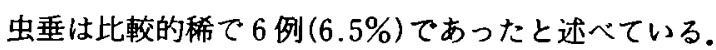

表 232191に1989年以降本邦で報告された魚骨によ る虫垂穿孔例17例に自験例 1 例を加えた18例をまとめ た. 男女比は15対 3 で男性に多く, 年齢は 43〜 78歳 (平 均年齢55.5歳)であった。13例に白血球の上昇を，12 例に CRP 上昇を認めた。術前に炎症反応や腹部腫留 などの異常所見を認めなかったのは, 自験例を含めて 2 例のみであった5). 魚骨長は平均 $2.3 \mathrm{~cm} て ゙ 1.1 \mathrm{~cm}$ か ら $5.0 \mathrm{~cm}$ まで長さはさまざまであった。

文献的には虫垂炎症状や腹膜炎症状を呈する急性炎 症型，肉芽腫を伴う膿瘍や腫瘤を形成する慢性炎症型 があり，病型は多彩といえる．前者は虫垂炎や頽室炎 と，後者は虫垂癌や粘液熟腫との鑑別が重要になる. 本症例は血液学的にも病理学的にも炎症所見は軽微で あり，虫垂より突出した先端鋭利な魚骨による腹膜へ の機械的刺激が右下腹部痛の原因と考えられた。2004 年に久下ら がか魚骨による虫垂穿孔で虫垂粘膜に炎症 を認めない例を報告しており, 通常の虫垂炎発症機序 と異なり, 純粋に先端鋭利な異物で虫垂穿孔が生じた
ことを病理学的に証明できたと述へている.また,2002 年に蛭川らら名が魚骨に上る蛙穿孔で，虫垂に炎症を 伴わず腹腔内炎症性腫㿔を形成した症例を初めて報告 しているが，本症例も診断が遅れた場合に同様の経過 をとった可能性がある.

術前診断はきわめて困難である。津田ら ${ }^{201}$ は CT 検 査が最も優れた検査法と述べている，われわれが集計 した18例中，CT 検查で魚骨を示唆する高吸収域を記 めたものは 7 例であり，また腹部超音波検査で魚骨を 示㖫する高エコー領域を認めたものは 6 例であった。 いずれの検査も検出率は高いとはいえない．またこれ らのうち術前に魚骨によると確定できた症例は 3 例て あった．画像所見が得られても，魚骨の可能性を念頭 に置かなければ, 確定診断に至らないものと思われる. 病悩期間が長いほど侵襲の大きい手術が施行される傾 向があるため, 早期診断, 早期治療が重要である゙. 本 症例は CT 検査, エコー検查とも所見にそしいのみな らず，血液検查的にも炎症所見に乏しく，腹部理学所 見のみで手術を施行した。各種検查で異常所見を認め なくとも，腹部の診察にて明らかな異常所見がある場 合はその所見を軽視してはならないと考えられた。

\section{結語}

魚骨による虫垂穿孔の 1 例を経験した．日常診療に おいて右下腹部痛の診断に難步することは多々あり， 各種検査法か開発された現在で理学的所見を軽視て きないことが示唆された症例であった。 


\section{文献}

1）石橋新太郎：腹腔内異物に関する臨床的ならびに 実験的研究. 日外会誌 $62 ： 489-509,1961$

2）松井昭彦，岡島邦雄，川西端哉他：魚骨による消 化管穿通の 2 治験例一症例報告ならびに本邦報告 121例の検討一. 日臨外会誌 $47: 955-961,1986$

3）久下博之, 吉村 淳, 豊川元邦：魚骨による虫垂 穿孔の 1 例. 日臨外会誌 $65: 2413-2416 ， 2004$

4）北原光太郎, 野口純也, 生天目信之地：魚骨に上 る虫垂穿孔の 1 例. 日臨外会誌 $65: 984-987$, 2004

5）二村直樹，松友将純，市橋正嘉他：魚骨による消 化管穿孔の 2 例。手術 $57: 367-369,2003$

6）犬飼道雄, 岡野圭一, 唐澤幸彦他：魚骨による虫 垂穿通の 1 例. 日消外会誌 $35: 1418-1422,2002$

7) 綛野 進, 塩見昌史, 李 昌人：興味ある画像を 呈した魚骨による回盲部炎症性肉芽腫の 1 例. 臨 外 $57: 857-859,2002$

8）蛭川浩史, 遠藤和彦, 後藤伸之他：虫垂を穿通し た魚骨による大網の炎症性腫瘤の 1 例. 日臨外会 誌 63：1013-1017，2002

9）築野和男, 丸山正董, 山崎達雄：魚骨制入が原因 となった急性虫垂炎の 1 例. 日消外会誌 $34: 114$ $-117,2001$

10）柴田 裕, 関 仁史, 上田 忠: 魚骨の虫垂穿通 が原因となった絞拒性イレウスの 1 例. 日臨外会 誌 $61: 1478-1481,2000$

11）稲川 智, 幸田圭史, 足立信也他：魚骨による虫
垂穿孔の 1 例. 日臨外会誌 $60 ： 1846-1849,1999$

12）藤村二郎，真田泰興，鈴木重道他：体外式超音波 検㚗及びCT 検查にて術前診断し得た魚写穿通に よる回盲部炎症性肉芽嗹の 1 例. J Med Ultra sonics $26: 17-22,1999$

13）志田誠一郎, 平川英典, 有島史芳他：魚骨の虫垂 迷入による限局性腹膜炎の 1 例. 日臨外会誌 $59: 1664-1668,1998$

14）小林利彦，木村泰三，高橋直記：魚骨の虫垂穿孔 による腹腔内膘曒の 1 例. 臨外 $52: 1089-1092$, 1997

15）遠近直哉，公文正光，荒木京二郎他：魚骨穿通に 上る虫垂炎の 1例. 外科治療 $74: 511-513,1996$

16）火爪健一，金崎照雄，吉野 武他：魚骨による消 化管穿通の 2 例. 外科診療 $35: 1447-1450,1993$

17）村瀬邦彦，橋本茂廣，大曲武征他：魚骨の虫垂穿 通による腹腔内膿瘏の 1 例.長崎医会誌 $66: 193$ $-196,1991$

18）飯田辰美，佐久間正幸，芹沢 淳他：魚骨による 虫垂の慢性炎症性肉芽腫の 1 治験例. 日消外会誌 $23: 1924-1927,1990$

19）樫塚登美男, 田中千凱，深田代造他：魚骨の腸管 穿孔による腹腔内膿瘍の 2 例. 救急医 $13: 371$ 375,1989

20）津田基晴, 鈴木 衛, 小山信二他：CT スキャンに よって術前に診断した魚骨穿通による腹腔腫瘤の 1 例. 臨外 $52: 1213-1216,1997$

\title{
A CASE OF PERFORATED APPENDIX BY A FISH BONE
}

\author{
Norifumi SHIGEMOTO, Yoshihiro SAKASHITA, Yasushi HASHIMOTO, \\ Michio TAKAMURA, Naru KONDO and Keishi KIN \\ Department of Surgery, Ohda Municipal Hospital
}

We experienced a case of perforated appendix by a fish bone that did not show obvious signs of inflammation. Patient was a 55-year-old male, who presented with a chief complaint of right lower quadrant abdominal pain. Physical examination suggested presence of appendicitis. The final diagnosis was made at the time of surgery as perforated appendix caused by a fish bone. It is quite rare to see a perforation of appendix by a fish bone swallowed by mistake. Eighteen such cases in including ours have been reported in Japan since 1989. Most of the cases were operated on with preoperative diagnosis of acute appendicitis of ileo-ceacal abscess with inflammatory signs, and only 3 cases had been correctly diagnosed preoperatively. In 2 cases blood study and image studies were normal. In this regard we believe careful physical examination of the patients are very important. A review of the literatures were done. 